Tinjauan Pustaka

\title{
Kelainan Hati akibat Penggunaan Antipiretik
}

\author{
Yusri Dianne Jurnalis, Yorva Sayoeti, Marlia Moriska
}

\begin{abstract}
Abstrak
Demam menyebabkan penderitaan pada anak dan kecemasan pada orangtua. Demam terjadi pada hampir sebagian besar anak setiap tahunnya. Antipiretik yang paling sering digunakan adalah acetaminophen, ibuprofen dan aspirin. Antipiretik ini dapat menyebabkan kelainan hati pada dosis tinggi dan pada penggunaan dosis terapi yang berulang. Baru-baru ini banyak digunakan obat kombinasi acetaminophen-ibuprofen. Tujuan penulisan artikel ini adalah untuk menjelaskan kelainan hati akibat penggunaan antipiretik. Penggunaan pada dosis terapi secara berulang harus sesuai indikasi, mempertimbangkan efek samping dan memahami dosis maksimal. Penggunaan obat kombinasi acetaminophen-ibuprofen harus diberikan hati-hati, dosis kandungan antipiretik harus dibaca lebih teliti. Perlu anamnesis yang jelas pada penegakan diagnosis dan perhitungan dosis total atau dosis rata-rata yang diterima. Klinisi harus dapat memonitor gejala kelainan hati akibat penggunaan obat-obatan antipiretik. Perlu komunikasi yang jelas, antara dokter dan keluarga pasien tentang keuntungan dan resiko pemberian antipiretik, baik itu penggunaan sekali saja ataupun berulang.
\end{abstract}

Kata kunci: antipiretik, ibuprofen, acetaminophen hepatoksik, drug induced hepatitis

\section{Abstract}

Fever causes misery for children and parental anxiety. It affects almost of children each year. The antipyretics most commonly used for treating fever are acetaminophen, ibuprofen and aspirin. These antipyretics can causes hepatotoxicity in high dose and in multiple daily doses. Recently, the use of combination acetaminophen-ibuprofen was widely use in child. The objective of this artikel was to learn more about how about antipyretics induced hepatotoxicity. The use of multiple daily doses must be in the right indication, considering the side effect and clear in maximal doses. The use of combination acetaminophen-ibuprofen must be with caution, composition of dose must be read cerefully. Its need good anamnesis and calculation of total dose or mean doses per day that received to make the right diagnosis. The better communication between physicians and families about the risks and benefits of use of antipyretic to prevent hepatotoxicity.

Keywords: antipyretic, acetaminophen hepatotoxicity, ibuprofen, drug induced hepatitis

Affiliasi penulis: Bagian IImu Kesehatan Anak Fakultas Kedokteran Universitas Andalas/RSUP Dr. M. Djamil Padang

Korespondensi: Yusri Dianne Jurnalis, E-mail:

yusridiane_jurnalis@yahoo.co.id, Telp: 081363931569

\section{PENDAHULUAN}

Demam menyebabkan penderitaan pada anak dan menjadi penyebab utama kecemasan pada orangtua. Demam terjadi pada hampir $70 \%$ anak-anak dibawah usia sekolah dan menyebabkan ketidaknyamanan, mengganggu aktifitas, menurunkan selera makan, mengganggu tidur pada anak dan orangtua. Orangtua akan sangat fokus untuk menurunkan demam, dengan pikiran akan menghilangkan ketidaknyaman, anak dapat kembali bermain, selera makan dapat kembali pulih, tidur dapat kembali baik, mencegah kejang, kerusakan otak dan lain-lain. Sehingga, tidak mengejutkan jika anak demam, orangtua akan langsung berusaha mendapatkan antipiretik atau langsung memberikan obat-obatan antipiretik tanpa konsultasi ke dokter., ${ }^{1,2}$ Acetaminophen atau paracetamol (N-acetyl-paraaminophenol atau APAP) adalah jenis obat-obatan golongan antipiretik yang paling luas digunakan di seluruh dunia. Orangtua sering memberikan terapi 
parasetamol pada suhu yang masih rendah $37,9 \mathrm{C}$, dengan pemberian lebih sering dari yang direkomendasikan karena juga digunakan bukan saja untuk mengatasi demam tapi juga untuk membuat anak lebih tenang, dan membantu anak beristirahat dan tidur lebih nyenyak. ${ }^{1-4}$ Ibuprofen merupakan golongan antipiretik kedua terluas digunakan setelah acetaminophen. Sekarang tersedia beberapa obat yang beredar di pasar dengan dua kombinasi obatobatan tersebut. 1,3,4 Penelitian Vernacchio di tahun 2009, mendapatkan pola penggunaan obat-obat antipiretik pada anak di berbagai usia. Pada usia 0-5 bulan, ditemukan penggunaan obat antipiretik hanya jenis acetaminophen saja sebesar $20 \%$ kasus. Mulai usia 6 bulan sampai $>36$ bulan mulai dikonsumsi obat antipiretik jenis ibuprofen saja, acetaminophen saja dan kombinasi acetaminophen-ibuprofen. Paling banyak penggunaan kombinasi acetaminophenibuprofen pada usia 6-11 bulan sebesar 5,9\%, penggunaan acetaminophen saja juga pada usia 6-11 bulan sebesar $28 \%$ dan ibuprofen saja pada usia 24 35 bulan sebesar $8,2 \% .{ }^{5}$ Acetaminophen hepatotoxicity baik secara accidental atau intentional, merupakan penyebab utama acute liver failure. Di United States, diperkirakan sebanyak 56.000 kunjungan di ruangan emergency setiap tahunnya, 2.600 rawat inap dan sekitar 500 kematian akibat acetaminophen hepatotoxicity. ${ }^{6}$ Penelitian Andabaka (2011) mendapatkan bahwa acetaminophen digunakan pada $29,8 \%$ kasus infeksi saluran nafas atas dengan tanpa konsultasi ke dokter. ${ }^{7}$ Sebuah laporan kasus pada anak post operasi, yang diberikan acetaminophen intravena, dan 12 jam kemudian ditemukan gejala mual, muntah, anorexia, confused, dan agitasi. Hasil pemeriksaan fungsi hepar, terdapat peningkatan kadar serum transaminase 10 kali dari normal. Setelah pengecekan ulang, ternyata anak mendapat acetaminophen 5 kali pada dosis $42 \mathrm{mg} / \mathrm{kgbb}$ (total 2,5 gram/30 menit atau $168 \mathrm{mg} / \mathrm{kgbb} / 24$ jam). ${ }^{8} \mathrm{Pada}$ acetaminophen hepatotoxicity terjadi akumulasi protein sehingga menyebabkan nekrosis centrilobular pada hati.6,9 Dosis toksik acetaminophen secara umum terjadi pada dosis > $150 \mathrm{mg} / \mathrm{kgbb}$ pada anak dibawah 12 tahun. Walaupun dosis tinggi acetaminophen berikatan erat dengan peningkatan resiko liver failure, namun penggunaan jangka panjang atau "chronic use" pada dosis standard ditemukan juga beresiko terhadap acetaminophen hepatotoxicity. Dilaporkan terdapat 2 kasus acute liver failure setelah pemberian acetaminophen hari ke-tiga dan kesepuluh. ${ }^{6}$ American academy of pediatric (AAP) menetapkan "chronic use" setelah mendapat beberapa kali dosis dalam 2 hari, juga ditemukan terjadi acetaminophen hepatotoxicity pada $51 \%$ kasus pada pemberian hari ke-tiga sampai hari ke-tujuh. ${ }^{10}$ Kasus ibuprofen hepatoxicity lebih jarang dilaporkan dibandingkan acetaminophen hepatotoxicity. Pada ibuprofen hepatotoxicity lebih sering terjadi kolestasis hepatoseluler. ${ }^{11}$ Oleh karena itu, penggunaan antipiretik per oral ataupun intravena harus tetap dalam aturan yang tepat oleh dokter dan dengan pertimbangan indikasi dan efek samping. Penggunaan produk obat-obatan yang mengandung campuran antipiretik dengan obat jenis lain, harus dibaca lebih teliti, dan tidak boleh diberikan dengan obat lain yang juga mengandung jenis yang sama. Perlu komunikasi yang jelas, antara dokter dan keluarga pasien tentang keuntungan dan resiko pemberian antipiretik, baik itu penggunaan sekali saja ataupun penggunaan jangka panjang. ${ }^{12,13}$ Tujuan artikel ini disusun adalah untuk menambah pengetahuan klinisi dalam penggunaan antipiretik dengan kaitan nya terhadap kelainan hati serta tatalaksananya.

\section{Antipiretik}

Antipiretik adalah golongan obat dengan target untuk menurunkan temperatur. Beberapa obat yang termasuk dalam golongan ini adalah Acetaminophen, Ibuprofen dan aspirin.

\section{Mekanisme obat-obatan menyebabkan}

\section{kelainan hati}

Terdapat dua mekanisme terpisah pada kelainan hati akibat obat yaitu hepatotoksisitas langsung atau karena efek samping obat (idiosinkrasi). Hepatotoksitas langsung timbul pada pemberian obat yang secara intrinsik bersifat toksik terhadap hati dan biasanya sifat toksik ini juga bergantung pada dosis yang diberikan. Hepatotoksin intrinsik ini dapat diduga menimbulkan kerusakan hati bila digunakan dalam dosis berlebihan. Kerusakan hati idiosinkrasi hanya terjadi pada sebagian kecil pengguna obat. 
Penyebabnya adalah kerentanan pasien terhadap obat yang digunakan, bukan karena efek toksik. Reaksi idiosinkrasi obat terjadi karena reaksi imunologis (hipersensitivitas) atau metabolik. Pada idiosinkrasi metabolik terjadi karena adanya metabolisme obat yang menyimpang pada orang yang bersangkutan yang menyebabkan kelainan hati. Reaksi hipersensitivitas diduga timbul pada anak dengan demam, ruam, dan eosinofilia, serta secara histologis ditemukan inflamasi hati eosinofilik atau granulomatosa. ${ }^{13}$ Pada umumnya kerusakan obat terjadi karena kerja metabolit aktif obat. Obat yang bersifat hepatotoksik intrinsik akandiubah oleh tubuh menjadi metabolit aktif melalui reaksi fase I pada semua pengguna obat tersebut. Sedangkan kerusakan hati karena idiosinkrasi metabolik adalah karena kecenderungan pengguna obat tersebut memproduksi metabolit toksik lebih banyak daripada pengguna obat pada umumnya. Idiosinkrasi imunologis bergantung pada metabolit aktif yang dihasilkan yang dapat berperan sebagai hapten. Konversi obat menjadi metabolit toksik dapat berupa radikal bebas, radikal elektrofilik, atau oksigen teraktivasi. Adanya radikal bebas berlebihan ini akan mengakibatkan kerusakan peroksidasi pada membran lipid. Pembentukan radikal elektrofilik akan terikat secara kovalen pada molekul membran sel dan akan mengganggu fungsi sel serta menyebabkan sel menjadi nekrosis. Metabolit elektrofilik juga dianggap dapat terikat secara kovalen dengan protein dan memproduksi neo-antigen yang menyebabkan reaksi idiosinkrasi imunologis. ${ }^{13}$

\section{Mekanisme acetaminophen menyebabkan kelainan hati}

Kerusakan hati akibat acetaminophen terjadi akibat suatu metabolitnya NAPQI (N-acetyl-pbenzoquinoneimine) yang sangat reaktif. Pada keadaan normal produk reaktif ini dengan cepat berikatan dengan kadar gluthation di hati, sehingga menjadi bahan yang tidak toksik. Akan tetapi pada keadaan kelebihan dosis, atau pemakaian terus menerus yang menyebabkan produksi NAPQI terus bertambah, dan tidak sebanding dengan kadar gluthathion, maka NAPQI berikatan membentuk makromolekul dengan sel hati yang mengakibatkan neksrosis sel hati. ${ }^{1,13,14}$ Kadar covalent binding yang menentukan kadar pengikatan dengan makromolekul dalam menyebabkan sel cedera ${ }^{15}$

\section{Mekanisme ibuprofen menyebabkan kelainan hati}

Kelainan hati akibat ibuprofen baru diketahui pada laporan kasus tahun 1977. Diketahui terjadi dengan berbagai klinis manifestasi dari fatty liver, peningkatan kadar transaminase dan kolestasis hepatitis. Sangat jarang dilaporkan kasus yang berkaitan dengan ibuprofen yang memerlukan transplantasi hepar. ${ }^{11}$ Kelainan yang mengakibatkan hepatotoksik ini diduga akibat bentuk "acyl glucosides" yang sangat reaktif. ${ }^{16}$ Kadar covalent binding pada ibuprofen hanya berikatan dengan hepatosit saja, ikatan dengan NADPH, UDPGA, GSH hanya berada dibawah kontrol sesuai dosis terapi, sehingga kelainan hati akibat ibuprofen tidak seberat acetaminophen.Kadar covalent binding aspirin dengan makromolekul didapatkan bahwa zat reaktif hanya memiliki ikatan dengan hepatosit saja, ikatan dengan NADPH, UDPGA, GSH hanya berada dibawah kontrol sesuai dosis terapi. ${ }^{15}$ Bentuk kelainan hati pada pemberian obat-obatan antipiretik acetaminophen hepatotoxicity. Kelainan akibat acetaminophen berupa tipe I (Nekrosis sel hati) dan tipe III (kolestasis: Hepatoselular/Kanalikuli). Dengan peningkatan enzim transferase AST/ALT +4 pada tipe I disertai peningkatan Alkali Phosphatase +1 , Kolesterol dapat normal atau menurun, seperti hepatitis. Pada kerusakan hati tipe III hepatoseluler terdapat peningkatan AST/ALT +1, alkali phospatase +3 , kolesterol meningkat +2 , dengan gejala obstruksi. Pada kerusakan hati tipe III kanalikuli terdapat peningkatan AST/ALT +1 , alkali phospatase +1 , kolesterol normal atau meningkat dengan gejala obstruksi. 1,13,14 Kelainan akibat Ibuprofen berupa tipe III (Kolestasis: Hepatoselular). ${ }^{10}$ Pada kerusakan hati tipe III hepatoseluler terdapat peningkatan AST/ALT +1 , alkali phospatase +3 , kolesterol meningkat +2 , dengan gejala obstruksi. ${ }^{13}$

Gambaran histologi hepar pada sel hati normal, akan tampak gambaran struktur lobular dari sel hepar tampak bersih dan hepatosit single layer yang menyebar pada daerah sekitar vena sentral, terdapat sitoplasma yang basofilik pada sel hepatosit. Pada acetaminophen hepatotoxicity, tampak gambaran area 
nekrosis centrilobular yang luas, degenerasi vacuolar dan infiltrasi sel inflammatori. ${ }^{9}$ Pada ibuprofen hepatotoxicity, menunjukkan hepatitis lobular dengan infiltrasi eosinophilic. ${ }^{11}$ (Gambar 1).

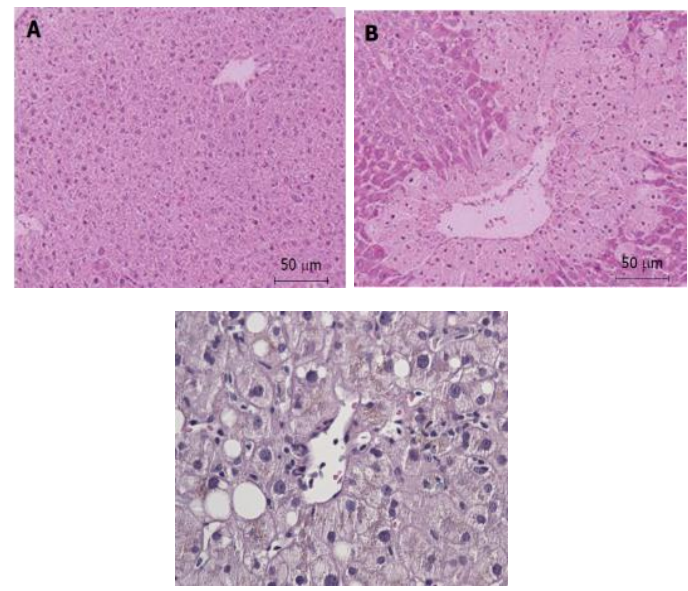

Gambar 1. Perbandingan gambaran histologi hepar
A. Sel hati normal. ${ }^{9}$
B. Acetaminophen hepatotoxicity. ${ }^{9}$
C. Ibuprofen hepatotoxicity. ${ }^{11}$

\section{Dosis Terapeutik dan Dosis Toksik Acetaminophen}

American Academy of Pediatrics (AAP) 2013 menyatakan dosis aman acetaminophen adalah pada $10-15 \mathrm{mg} / \mathrm{kgbb} / \mathrm{kali}$ dengan frekuensi pemberian $\leq 5$ kali sehari, dosis maksimal sehari $75 \mathrm{mg} / \mathrm{kgbb}$ per hari, 3,10 dan maksimal $90 \mathrm{mg} / \mathrm{kgbb} / \mathrm{hari}$ pada penggunaan 3 hari. ${ }^{3}$ NHS Clinical Knowledge Summaries menyatakan dosis yang diberikan harus per kgbb, dengan pemberian $15 \mathrm{mg} / \mathrm{kgbb}$, pemberian selanjutnya dengan interval paling cepat 6 jam. ${ }^{1}$ Shann di tahun 2013, menyatakan dosis acetaminophen oral dan intravena dimulai pada dosis $20 \mathrm{mg} / \mathrm{kgbb}$, kemudian $15 \mathrm{mg} / \mathrm{kgbb}$ setiap 4-6 jam, dengan kadar maksimal 4 gram/hari atau dosis 60 $\mathrm{mg} / \mathrm{kgbb}$, dan maksimal dalam 48 jam hanya $90 \mathrm{mg} / \mathrm{kgbb}$. Penggunaan pada neonatus usia $<10$ hari dengan dosis 7,5 mg/kgbb, neonatus usia $>10$ hari 15 $\mathrm{mg} / \mathrm{kgbb}$ dengan pemberian setiap 6 jam. Pada pemberian per rectal dimulai dengan dosis 40 $\mathrm{mg} / \mathrm{kgbb}$, kemudian turun $30 \mathrm{mg} / \mathrm{kgbb}$, dengan pemberian setiap 6 jam, maksimal dosisi per rectal 5 gram/hari. ${ }^{17}$ Dosis toksik acetaminophen secara umum terjadi pada dosis $>150 \mathrm{mg} / \mathrm{kgbb}$ pada anak dibawah 12 tahun. ${ }^{11}$ Literatur lainnya menyatakan dosis toksik terjadi bila pemakaian lebih dari $160 \mathrm{mg} / \mathrm{kgbb} / \mathrm{hari}^{10}$
Belum jelas apakah terdapat perbedaan efek hepatotoksik antara pemberian acetaminophen dosis per oral dengan intravena. Terapi antidotum pada kondisi setelah 24 jam acetaminophen hepatotoxicity ini juga masih kontroversial apakah bermanfaat atau tidak. Terapi antidotum direkomendasikan pada anak yang mendapat dosis $>150 \mathrm{mg} / \mathrm{kgbb} / \mathrm{hari}$ selama 1 sampai 2 hari atau lebih dan/atau pasien dengan level acetaminophen diatas $10 \mu \mathrm{g} / \mathrm{ml}$ walaupun setelah 24 jam. Di Amerika Serikat, masih berdasarkan opini ahli, pemberian antidotum dimulai pada pemberian acetaminophen intravena $60 \mathrm{mg} / \mathrm{kgbb}$ atau dengan konsentrasi $50 \mathrm{mg} / \mathrm{L}$ pada 4 jam. ${ }^{12}$ Namun, pada individu yang sama, dosis toksik dapat juga terjadi pada pemakaian dalam dosis terapi dan penggunaan berulang. Hal ini berhubungan dengan menurunnya kadar gluthation pada keadaan kelaparan, kurang gizi dan penggunaan alkohol. Dikatakan bahwa pada anak usia dibawah 12 tahun, sifat hepatotoksik dari acetaminophen berkurang jika dibandingkan dengan anak yang lebih besar. Hal ini disebabkan karena kadar sitokrom P-450 yang rendah sehingga metabolisme acetaminophen juga berkurang. ${ }^{13}$

\section{Ibuprofen}

AAP (2013) menyatakan dosis aman ibuprofen adalah pada $10 \mathrm{mg} / \mathrm{kgbb} / \mathrm{kali}$ dengan frekuensi pemberian setiap 6 jam, dosis maksimal sehari 40 $\mathrm{mg} / \mathrm{kgbb}$ per hari. $^{3}$ NHS Clinical Knowlegde Summaries menyatakan dosis aman untuk ibuprofen adalah $10 \mathrm{mg} / \mathrm{kgbb}$, dengan pemberian selanjutnya dengan interval paling cepat 6 jam. ${ }^{1}$ Shann (2013) menyatakan dosis lbuprofen 5-10 mg/kgbb dengan pemberian tiap 4-8 jam. ${ }^{17}$

\section{Aspirin}

Dosis aspirin 10-15 mg/kgbb dengan pemberian tiap 4-6 jam. ${ }^{17}$

\section{Penggunaan kombinasi acetaminophen- ibuprofen}

Antipiretik kombinasi acetaminophen dan ibuprofen mulai sering digunakan dalam mengatasi demam. Terdapat 5 penelitian yang membandingkan penggunaan kombinasi acetaminophen-ibuprofen dengan monoterapi acetaminophen saja atau 
ibuprofen saja. Penelitian pertama dari 89 anak di India dengan suhu aksila $>38,5$ Celsius. Anak-anak tersebut menerima ibuprofen $10 \mathrm{mg} / \mathrm{kgbb}$ saja, parasetamol saja $10 \mathrm{mg} / \mathrm{kgbb}$ dan kombinasi acetaminophen $10 \mathrm{mg} / \mathrm{kg}$ bb-ibuprofen $10 \mathrm{mg} / \mathrm{kgbb}, 3$ kali sehari. Hasilnya didapatkan bahwa kombinasi acetaminophen-ibuprofen lebih efektif dibandingkan dengan acetaminophen saja pada 0,5-2 jam, dan kurang efektif dari 10-24 jam, namun perbedaan suhu antara kombinasi dengan monoterapi hanya kurang dari 1 Celsius. ${ }^{1}$ Penelitian kedua penelitian acak pada 123 anak di emergensi Amerika Serikat dengan suhu timpani $\geq 38$ Celsius. Anak-anak tersebut menerima acetaminophen $15 \mathrm{mg} / \mathrm{kgbb}$ atau ibuprofen $5 \mathrm{mg} / \mathrm{kgbb}$ atau kombinasi kedua obat tersebut, kemudian dilakukan pengukuran suhu kembali pada 1 jam kemudian. Walaupun didapatkan hasil yang bermakna berbeda antara obat monoterapi dengan kombinasi namun perbedaan obat kombinasi acetaminophenibuprofen dengan acetaminophen monoterapi hanya 0,35 Celsius dan ibuprofen monoterapi hanya 0,25 Celsius. Target penelitian ini adalah terdapat perbedaan suhu 1 Celsius antara obat kombinasi dibanding monoterapi sehingga $\mathrm{Cl}$ penelitian tersebut menolak nilai kepentingan klinis pada penggunaan kombinasi dibanding monoterapi. Penelitian ketiga juga penelitian acak pada 464 anak dengan suhu rectal $>38,4$ pada rawat jalan di Israel. Anak-anak tersebut mendapat acetaminophen $12,5 \mathrm{mg} / \mathrm{kgbb}$ setiap 6 jam, ibuprofen $5 \mathrm{mg} / \mathrm{kgbb}$ setiap 8 jam dan kombinasi acetaminophen-ibuprofen setiap 4 jam. Didapatkan hasil perbedaan suhu 0,8 -1,1 Celsius antara obat kombinasi dengan monoterapi.Penelitian ke-empat juga penelitian acak pada 70 anak usia 6 bulan-12 tahun di Lebanon dengan suhu rectal $\geq 38,8$ Celsius. Anak-anak tersebut mendapat tambahan acetaminophen $15 \mathrm{mg} / \mathrm{kgbb}$ atau plasebo pada 4 jam setelah tercapai dosis basal ibuprofen $10 \mathrm{mg} / \mathrm{kgbb}$. Hasilnya didapatkan pada kelompok mendapat acetaminophen setelah 4 jam ibuprofen mengalami afebrile dalam 6 jam $83 \%$ vs 58\%.Penelitian kelima sebuah penelitian acak pada 38 anak usia 6 bulan -6 tahun yang mendapat acetaminophen $15 \mathrm{mg} / \mathrm{kgbb}$ pada waktu 0 dan 4 jam dan kelompok menerima acetaminophen $15 \mathrm{mg} / \mathrm{kgbb}$ kombinasi ibuprofen 10 $\mathrm{mg} / \mathrm{kgbb}$ pada waktu 0 dan 3 jam. Perbedaan suhu baru terlihat pada jam ke 4 dan 5. ${ }^{1}$ Penelian Hay et al di tahun 2009, melakukan penelitian pada anak usia 6 bulan- 6 tahun dengan suhu $\geq 37,8$ Celsius dan $\leq 41$ Celsius. Mereka mendapat acetaminophen saja 15 $\mathrm{mg} / \mathrm{kgbb}$, ibuprofen saja $10 \mathrm{mg} / \mathrm{kgbb}$ dan kombinasi. Hasilnya obat kombinasi lebih cepat membebaskan demam dibanding dengan acetaminophen saja, namun tidak lebih cepat dibanding dengan ibuprofen saja. Hay et al menyimpulkan bahwa pada anak usia dini dengan demam dianjurkan untuk menggunakan ibuprofen terlebih dahulu, jika dosis pertama ibuprofen telah diberikan namun anak masih demam, penggunaan obat kombinasi setelah itu lebih efektif dibanding monoterapi ibuprofen saja ataupun acetaminophen saja. Jika kedua obat kombinasi ini digunakan, Hay et al menganjurkan untuk mencatat dosis total per hari agar tidak melampaui dosis maksimal sehingga tidak menimbulkan efek samping yang serius. ${ }^{1}$ Hasil survei Vernachio et al pada tahun 2009, ditemukan bahwa tidak terdapat penggunaan ibuprofen monoterapi pada usia 0-5 bulan, yang dinyatakan konsisten dengan labelling produk. Pada usia 6 bulan mulai digunakan obat kombinasi acetaminophen-ibuprofen. ${ }^{5}$ Walaupun terdapat beberapa penelitian menunjukkan bukti bahwa obat kombinasi lebih efektif dibanding monoterapi setelah 4 sampai 5 jam terapi, namun keamanan obat kombinasi tersebut belum dapat ditentukan. Orangtua dapat tidak mengerti tentang regimen dosis dan kemudian hal tersebut menyebabkan kondisi dosis yang salah, terjadinya overdosis dan efek samping yang lebih besar. Penggunaan obat kombinasi ini harus dengan "caution" atau "peringatan"/"hati-hati". Penelitian lebih lanjut perlu untuk menegakkan bahwa obat kombinasi dapat diberikan secara rutin dengan aman pada anak demam. Klinisi harus dapat memonitor keluhan dan gejala dari efek samping obat. ${ }^{4}$

\section{Diagnosis}

Diagnosis penyakit hati akibat obat-obat bergantung pada anamnesis dan pemeriksaan fisik yang teliti dan perlu mencakup halsebagai berikut:

\section{a. Acetaminophen Hepatotoxicity}

Kondisi klinis acetaminophen hepatotoxicity dapat berupa muncul bercak ruam merah, urtikaria, sesak nafas, diare, hipotermia, nyeri perut, confused, 
dan agitasi. ${ }^{1}$ Hasil pemeriksaan didapatkan peningkatan kadar transminase serum (ALT dan AST), penurunan kadar GSH. Pada anamnesis terdapat awitan penggunaan acetaminophen mendahului timbulnya gejala tersebut. Jika mencurigai suatu kasus acetaminophen hepatotoxicity, sebaiknya pastikan terlebih dahulu apakah kasus tersebut "single dose" atau "chronic use". Jika "single dose", maka harus ditentukan berapa dosis total yang didapat dan kapan waktu pasti pemberian. Jika kasus tersebut adalah "chronic use", maka data yang harus didapatkan adalah rata-rata dosis yang didapat setiap hari dan lama pemberian. AAP menetapkan "chronic use" pada penggunaan $\geq 2$ hari. Kasus acetaminophen pada "single dose" lebih mudah didiagnosis daripada kasus "chronic use". Sejumlah $22 \%$ kasus "chronic use" dapat didiagnosis oleh dokter yang pertama kali menerima, dan 97\% pada "single use". ${ }^{10}$ Dosis toksik acetaminophen secara umum terjadi pada dosis $>150$ mg/kgbb. ${ }^{12}$ AAP 2013 mendapatkan, kejadian acetaminophen terjadi pada mayoritas $51 \%$ "chronic use" pada lama pemberian 3 sampai 7 hari, 36\% pada 2 hari pemberian, $4 \%$ pada 8 sampai 14 hari pemberian, dan $9 \%$ pada > 15 hari pemberian. Perbedaan dosis "chronic use" dengan "single use" adalah 31 (15,1-52,4 mg/kgbb/hari) vs $258 \mathrm{mg} / \mathrm{kgbb}$ $(135,9-378,4 \mathrm{mg} / \mathrm{kgbb})$. Bagaimanapun kedua kelompok memiliki serum APAP yang hampir mirip $\geq$ $10 \mathrm{mg} / \mathrm{L}$ (68\% vs $66 \%) .{ }^{10}$

\section{b.Ibuprofen hepatotoxicity}

Pada anamnesis terdapat awitan penggunaan ibuprofen mendahului timbulnya gejala. Kelainan hati akibat ibuprofen dapat terjadi dengan berbagai klinis manifestasi dari fatty liver, peningkatan kadar transaminase, dan kolestasis hepatitis. ${ }^{11}$ Aspirin hepatotoxicityHepatotoksik karena aspirin ditandai oleh kadar aspirin dalam serum yang melebihi 25 $\mathrm{mg} / \mathrm{dl}$ dan sering meningkatkan kadar enzim transminase. Kadar AST dan/atau ALT meningkat dan menimbulkan eosinofilia. Kadang terdapat anoreksia, mual, muntah, nyeri perut dan hepatomegali. Pada kasus overdosis aspirin, terjadi ikterus yang progresif, dan pada biopsi terlihat infiltrasi sel mononuklear dan sel-sel nekrosis. Dengan mikroskop elektron terlihat mitokondria edem. Sebuah kasus hepatotoksik yang berkaitan erat dengan penggunaan aspirin dosis rendah pada anak kecil setelah mendapat transplantasi hati, terdapat asimtomatik peningkatan AST/ALT, pada biopsi hepar ditemukan nekrosis hepatoselular. ${ }^{14}$ Pada kebanyakan kasus, klinis aspirin hepatotoksik adalah seperti hepatitis, anorexia, mual, muntah, nyeri perut dan peningkatan AST/ALT, walaupun jarang terjadi peningkatan dapat melebihi 1000 IU. Hepatomegali hampir selalu terjadi, tetapi kerusakan hati seperti ikterik dan koagulopati jarang terjadi. Kelainan klinis dan laboratorium dapat kembali seperti semula jika pemberian aspirin dihentikan. Histologi hepar menunjukkan gambaran yang tidak spesifik dengan acute focal nekrosis hepatoseluler. ${ }^{14}$ Prognosis Jika obat-obatan yang menyebabkan kelainan hati dihentikan segera saat gejala klinis dan pemeriksaan mengarah kepada hepatotoksik akibat obat, maka pada gejala ringan dan sedang dapat mengalami perbaikan. Kadang-kadang perbaikan terjadi lambat bila kelainan hati yang diakibatkan berat. ${ }^{13,14}$ Pada ibuprofen hepatotoxicity jarang yang menyebabkan transplantasi. ${ }^{11}$ Penelitian Leonis et al (2013) menilai hasil luaran setelah 21 hari follow up pasien acetaminophen hepatotoxocity mendapatkan $5,9 \%$ kasus "single dose" membutuhkan transplantasi, dan 20,5\% "chronic use" juga membutuhkan transplantasi hati. Sebesar $12 \%$ pasien "chronic use" acetaminophen meninggal tanpa transplantasi, dan 2,4\% kasus meninggal tanpa transplantasi pada "single dose". Sejumlah 67,5\% kasus hidup tanpa transplantasi pada "chronic use" dan 91,8\% kasus hidup tanpa transplantasi pada "single dose". ${ }^{10}$

\section{Tatalaksana}

Tatalaksana yang paling efektif adalah menghentikan obat penyebab kelainan hati tersebut. Kadang-kadang perbaikan lambat terjadi atau bila sangat berat umumnya tidak dapat membaik. Untuk acetaminophen hepatotoxicity tersedia antidotum spesifik, yaitu:

\section{a.N-Asetilsistein (NAC)}

Pemberian NAC dalam 16 jam pertama setelah dosis toksik dapat meminimalkan kerusakan hati dan mencegah penyakit hati yang fatal pada hampir semua pasien. Hasil konsensus terakhir obat ini masih dapat 
memberi manfaat bila diberikan dalam 24 jam pertama. Dosis inisial NAC oral adalah $140 \mathrm{mg} / \mathrm{kgbb}$ dilanjutkan $70 \mathrm{mg} / \mathrm{kgbb}$ setiap 4 jam sampai dengan 16 jam berikutnya. Pencegahan kerusakan hati dilakukan dengan pengeluaran residu acetaminofen dari lambung dengan cara melakukan bilas lambung. Bilas lambung akan efektif bila dilakukan dalam 2-3 jam pertama setelah menelan acetaminofen, tetapi tindakan ini tetap dianjurkan walaupun telah lewat periode tersebut karena mungkin saja masih terdapat residu di lambung. Fosfat serum bila ditemukan tinggi merupakan indikator yang sangat spesifik dan sensitif untuk memprediksi pasien yang tidak dapat bertahan. ${ }^{13}$ NAC merupakan suatu antioksidan, yaitu sumber glutation yang efektif mencegah proses oksidasi pada tubuh. NAC merupakan suatu "prodrug" dan prekursor GSH. Langkah laju terbatas dalam biosintesis GSH dikatalisis oleh Glutamat Cistein Ligase (GCL) sebuah heterodimer terdiri dari katalitik dan pengubah (GCLM) subunit. Pemberian NAC pada acetaminophen hepatotoxicity merupakan standard klinis praktis. ${ }^{18}$ NAC merupakan obat golongan mukolitik yang telah lama digunakan. tetapi juga memberikan efek yang menguntungkan pada penyakit yang berkaitan dengan stress oksidatif. Pada tahun 1990an terdapat beberapa uji klinis terbuka yang mengindikasikan NAC intravena dapat meningkatkan hemodinamik dan transport oksigen pada "acute liver failure" pada beberapa variasi, sehingga NAC digunakan secara luas pada ICU (Intensive Care Units) pada penyakit hati. ${ }^{18}$ NAC merupakan antidotum efektif pada acetaminophen hepatotoxicity. Protokol terbaru merekomendasikan dosis awal NAC 150 $\mathrm{mg} / \mathrm{kg}$, diberikan secara infus selama satu jam, diikuti dengan penurunan jumlah NAC untuk 20 jam berikutnya. Kerusakan fatal pada hati dapat di cegah dengan pemberian inisial dosis NAC pada 8-12 jam setelah pemberian acetaminophen yang berlebihan. ${ }^{6}$

Efek NAC memproteksi hepar akibat acetaminophen dengan menyediakan CYS sebagai prekursor GSH, sehingga menghambat pembentukan NAPQ1, sehingga mengurangi efek toksik. Rasio Hepatic Cytokine TNF-a/IL-6 menurun signifikan. Rasio ini dianggap sebagai perbandingan proinflammatory/anti-inflammatory index. Pada pemberian NAC, index tersebut dapat mencapai
0,327, dari efek acetaminophen hepatotoxicity 0,512. Penelitian Yang et al pada tahun 2009, mendapatkan hasil yang berbeda. Pada pemberian NAC setelah 24 jam acetaminophen hepatotoxicity, NAC meningkatkan kadar serum transminase (ALT dan AST), menginduksi hepatocyt vacuolation pada area periportal dan menyebabkan perlambatan dari regenerasi sel hepar. Efek ini dicurigai berkaitan dengan penurunan hepatic NF-kB DNA binding dan penurunan ekspresi dari cell cycle protein cyclin D1, yang merupakan dua faktor utama pada regenerasi hepar. ${ }^{20}$

Penelitian Bateman et al (2014) melakukan penelitian pemberian modifikasi NAC dengan waktu pemberian 12 jam. Standard pemberian sebelumnya diberikan durasi 20-25 jam, dengan cara $150 \mathrm{mg} / \mathrm{kgbb}$ dalam $200 \mathrm{ml}$ selama 15 menit, $50 \mathrm{mg} / \mathrm{kgbb}$ dalam 0,5 L selama 4 jam, dan 100 mg/kgbb dalam $1 \mathrm{~L}$ selama 16 jam. Namun penelitian ini memberikan 100 $\mathrm{mg} / \mathrm{kgbb}$ dalam $200 \mathrm{ml}$ selama 2 jam, $200 \mathrm{mg} / \mathrm{kgbb}$ dalam $1 \mathrm{~L}$ selama 10 jam dan 0,5 L cairan Dextrose 5\% selama 20-25 jam. Hasilnya didapatkan bahwa secara klinis (muntah, demam, anafilatik dll) tampak lebih cepat perbaikan pada pemberian regimen 12 jam, walau kadar ALT dan AST tidak jauh berbeda. ${ }^{21}$

\section{b.Glutathione (GSH)}

Pemberian GSH hampir menyerupai pada pemberian NAC, dengan target recovery kadar GSH, namun GSH lebih efektive $82 \%$ dibanding NAC, karena langsung diberikan dalam bentuk GSH. Pemberian dosis GSH ini masih dalam penelitian, namun Saito et al (2010) meneliti pemberian GSH pada dosis $200 \mathrm{mg} / \mathrm{Kgbb}$; 0,65 mmol/kgbb menunjukkan hasil yang bermanfaat pada acetaminophen hepatotoxicity. ${ }^{22}$

\section{c. Adenosyl S-L-metionin-(SAMe)}

Pemberian SAMe sebelum pemberian acetaminophen dapat mencegah terjadinya centrolobular necrosis. SAMe merupakan suatu zat yang terkandung pada plasma dan sebagian besar jaringan. SAMe telah dapat dijual secara komersil sebagai suplemen makanan yang bergabung bersama vitamin dan makanan kesehatan. Prinsipnya SAMe merupakan donor methyl dalam tubuh untuk proses 
transmetilasi. Faktor utama dari proses transmetilasi adalah hati. SAMe merupakan precursor vital untuk jalur trans-sulfurasi. Produk akhir trans-sulfurasi adalah gluthatione. SAMe lebih hepatoprotektif untuk mengatasi efek toksik acetaminophen dari NAC, karena alanine aminotransferase tingkatnya lebih rendah pada pemberian SAMe. Total GSH dipertahankan lebih tinggi dari NAC. Stres oksidatif lebih sedikit pada kelompok SAMe. ${ }^{23}$

\section{d. 2,4-dihydroxybenzophenone (BP-1)}

2,4-dihydroxybenzophenone (BP-1) merupakan turunan benzofenone. Penelitian $\mathrm{He}$ et al (2011), meneliti efek BP-1 dosis $200 \mathrm{mg} / \mathrm{kgbb}, 400 \mathrm{mg} / \mathrm{kgbb}$, dan $800 \mathrm{mg} / \mathrm{kgbb}$, dengan pemberian setiap hari, 4x sehari sebelum pemberian acetaminophen dosis toksik $350 \mathrm{mg} / \mathrm{kgbb}$ secara subkutan. Pada 24 jam kemudian acetaminophen hepatotoxicity, kemudian diperiksa serum alanine aminotransferase (ALT), aspartate aminotransferase (AST), lactate dehydrogenase (LDH) dan dilakukan pemeriksaan histopatologis. Hasilnya didapatkan bahwa: ${ }^{9}$

- Pemberian BP-1 dapat mengurangi serum ALT, AST dan LDH yang meningkat secara dramatis pada dosis $400 \mathrm{mg} / \mathrm{kgbb}$ dan $800 \mathrm{mg} / \mathrm{kgbb}$.

- Pemberian BP-1 dapat menurunkan kadar MDA dan meningkatkan rasio GSH/GSSG

- Pemberian BP-1 mencegah kerusakan sel hati. Pada dosis $200 \mathrm{mg} / \mathrm{kgbb}$ tidak efektif mencegah kerusakan sel hati, namun pada dosis 400 $\mathrm{mg} / \mathrm{kgbb}$ kerusakan hanya menunjukkan kerusakan sedang dan pada dosis $800 \mathrm{mg} / \mathrm{kgbb}$ hampir mendekati struktur normal hepar pada kelompok sehat.

\section{e. Salidroside (SDS)}

Salidroside (SDS) diisolasi dari Rhodiola sacha-linensis. Diberikan secara oral pada dosis 50 100 mg/kgBB 2 jam sebelum pemberian paracetamol. SDS signifikan memproteksi hapatosit lebih baik daripada NAC. SDS menghambat peningkatan AST, ALT dan TNF-a, serta menginduksi GSH depletion dan MDA akumulasi, ekspresi HIF-1a pada jaringan hati. ${ }^{24}$

\section{f.Thiacremonone}

Thiacremonone diisolasi dari bawang putih, dengan susunan 2,4-dyhydroxy-2,5-dimethylthiophene-3-one. Thiacremonone memiliki efek anti-inflamasi dengan sifat inhibisi pada jalur NF-kB. Penelitian Kim et al (2013) menyatakan bahwa:25

- Thiacremonone menurunkan 50\% kejadian acetaminophen hepatotoxicity.Pada pemberian 10, 20, dan $50 \mathrm{mg} / \mathrm{kgbb}$ thiacremonone meningkatkan angka recovery 58,3\%, 83,3\% dan $100 \%$. Terdapat perbedaan yang signifikan pada kadar ALT dan AST pada kelompok yang diberi thiacremonone dibanding kontrol. Lesi patologis pada pemeriksaan histopatologis yang terjadi pada kelompok yang mendapat thiacremonone lebih minimal dibandingkan kelompok kontrol.

- Thiacremonone menghambat deplesi GSH, overproduksi NO, dan Lipid peroxidase via Inhibisi pada ekspresi Cytochrome P450 2E1.

- Thiacremonone menghambat overproduksi proinflamatory cytokine. Level IL-1a, IL-7, IL-17, I309 (chemokine C-C motif ligand 1, CCL1), MCSF (macrophage colony-stimulating factor), MIG (C-X-C motif ligand 9, CXCL9), MIP-1a (CCL3), dan MIP-1 $\beta$ (CCL4) meningkat pada APAP intoksikasi. Semua jenis cytokine tersebut menurun setelah pemberian thiacremonone.

- Thiacremonone menurunkan aktifitas NF-kB dan STAT-1 pada jaringan hepar.

- Thiacremonone menurunkan APAP-induced infiltrasi sel imun sitotoksik.

\section{g. Diphenyl Diselenide atau (PhSe)2}

Diphenyl Diselenide merupakan kelompok antioksidan dan antiinflammatory organoselenium. Efek hepatoprotektif berkaitan dengan penyediaan hidrogen peroksidase dan hidroperoksidase lainnya yang berperan besar pada gluthatione peroxidase. Pemberian dosis $15,6 \mathrm{mg} / \mathrm{kgb}$ pada pasien acetaminophen hepatotoxicity, ditemukan hasil yang lebih baik berupa penurunan penanda stress oksidatif (lipid peroksidase, reactive species dan protein carbonylation), peningkatan antioxidan defense pada 
sel hepar dan mitokondria. Jenis obat ini memperbaiki homeostasis mitokondria, memperbaiki mitokondria disfungsi akibat perubahan permeabilitas membran akibat acetaminophen. ${ }^{26}$

Penggunaan antipiretik baik per oral ataupun intravena haruslah dengan memperhitungkan dosis dan aturan yang benar. Penggunaan pada dosis terapi secara berulang harus sesuai indikasi dan mempertimbangkan efek samping, karena hasil luaran hepatotoksik pada penggunaan acetaminophen "chronic use" tidak sama dengan penggunaan "single use“. Perlu anamnesis yang jelas pada penegakan diagnosis dan perhitungan dosis total atau dosis ratarata yang diterima untuk menentukan kelainan hati akibat penggunaan antipiretik. Penggunaan obat kombinasi acetaminophen-ibuprofen harus dengan hati-hati, sehingga penggunaan produk obat-obatan yang mengandung kombinasi antipiretik harus dibaca lebih teliti, dan tidak boleh diberikan dengan obat lain yang juga mengandung antipiretik. Orangtua dapat tidak mengerti tentang regimen dosis dan kemudian hal tersebut dapat menyebabkan penggunaan dosis yang salah, terjadinya overdosis dan efek samping yang lebih besar. Dan yang paling penting, klinisi harus dapat memonitor keluhan dan gejala dari efek samping obat-obatan antipiretik. Penghentian penggunaan obat-obatan harus segera dilakukan saat kecurigaan ditegakkan. Pemberian antidotum pada acetaminophen hepatoxicity dapat mencegah komplikasi yang lebih berat. Perlu komunikasi yang jelas, antara dokter dan keluarga pasien tentang keuntungan dan resiko pemberian antipiretik, baik itu penggunaan sekali saja ataupun penggunaan jangka panjang. ${ }^{26}$

\section{DAFTAR PUSTAKA}

1. Hay AD, Redmond NM, Costelloe C, Montgomery AA, Fletcher M, Hollinghurst $S$, et al. Paracetamol and ibuprofen for the treatment of fever in children: the pitch randomised controlled trial. Health technology assessment. 2009;13:1-183.

2. Jensen JF, Tonnesen LL, Soderstrom M, Thorsen $\mathrm{H}$, Siersma V. Paracetamol for feverish children: parental motives and experiences. Scandinavian J of Primary Health Care. 2010; 28: 115-20.
3. Sullivan JE, Farrar HC. Fever and antipyretic use in children. Pediatrics. 2011;127:580-7.

4. Hoover L. AAP reports on th use of antipyretics for fever children. American academy of family physicians. 2012;85:1-2.

5. Vernacchio L, Kelly JP, Kaufman DW, Mitchell AA. Medication use among children $<12$ years of age in the United States: Results From the Slone Survey. Pediatrics. 2009;124;446-57.

6. Ben Shachar R, Chen Y, Luo S, Hartman C, Reed M, Nijhout HF. The biochemistry of acetaminophen hepatotoxicity and rescue: a mathematical model. Theoretical biology and medical modeling. 2012;9:1-22.

7. Andabaka T, Globocnik T, Vukelic D, Esposito S, Barsic B. Parental adminstration of antipyretics to children with upper respiratory tract infections without consultation with physician. Clin sciences. $2011 ; 52: 48-54$

8. Orun E, Polat A, Andan H, Cizmeci N, Tufan N. Incorrect prescription of intraveous paracetamol in a pediatric patient. Hippokratia. 2013;17:77-8.

9. He YY, Zhang BX, Jia FL. Protective effects of 2,4dihydroxybenzophenone againts acetaminopheninduced hepatotoxicity in mice. World $\mathrm{J}$ Gastroenterol. 2011;17:2663-6.

10. Leonis MA, Alonso EM, Im K, Belle SH, Squires $\mathrm{RH}$. Chronic acetaminophen exposure in pediatric acute liver failure. Pediatrics. 2013; 131:740-6.

11. Nayudu SH, Kavuturu S, Niazi M, Daniel M, Dev A, Kumbum K. A rare coexistence: Drug induced hepatitis and meningitis in association with ibuprofen. J Clin Med Res. 2013; 5:243-6.

12. James L, Sullivan JE, Robert D. The proper use of acetaminophen. Paediatr Child Health. 2011;16:544-7.

13. Rosalina I. Drug induced hepatitis. Dalam: Juffrie M, Soenarto SSY, Oswari H, Arief S, Rosalina I, Mulyani NS, editor (penyunting). Buku Ajar Gastroenterologi - Hepatologi. Jakarta: Badan Penerbit IDAI; 2010. hlm.329-38.

14. Roberts EA. Drug- induced liver disease. Dalam: Suchy FJ, Sokol RJ, Balisteri WF, editor (penyunting). Liver Disease In Children. New York: Cambridge University Press; 2007. hlm.478-512. 
15. Usui T, Mise M, Hashizume T, Yabuki M, Komuro S. Elevation of the potential for drug-induced liver injury besed on in vitro covalent binding to human liver protein. Drug Metabolism And Disposition. 2009; 37:2383-92.

16. Buchheit D, Dragan CA, Schmitt EI, Bureik M. Production of ibuprofen acyl glucoside by human UGT2B7. Drug Metabolism And Disposition. 2011; 39:2174-81.

17. Shann F. Drug doses. Australia: Royal Children Hospital; 2013:1-97.

18. Mirja-Liisa A. N-acetylcysteine - passe-partout or much ado about nothing? $\mathrm{Br} \mathrm{J}$ Clin Pharmacol. 2005; 61:5-15.

19. Masubuchi Y, Nakayama J, Sadakata Y. Protective effects of exogenous glutathione and related thiol compounds againts drug-induced liver injury. Biol Pharm Bull. 2011;34:366-70

20. Yang R, Miki K, He X, Killeen ME, Fink MP. Prolonged treatment with $n$-acetylcystine delays liver recoverty from acetaminophen hepatotoxicity. Critical care. 2009;13:1-7.

21. Bateman DN, Dear JW, Thanacoody HK, Thomas S, Eddleston M, Sandilands EA, et al. Reduction of adverse effects from intravenous acetylcysteine treatment for paracetamol poisoning: a randomised controlled trial. Lancet. 2014; 383:697-704.

22. Saito C, Zwingmann C, Jaeschke H. Novel mechanism of protection againts acetaminophen hepatotoxicity in mice by glutathione and $n$ acetylcysteine. Hepatology. 2010; 5:246-54.

23. Terneus MV, Kiningham KK, Carpenter AB, Sullivan SB, Valentovic MA. Comparison of Sadenosyl-I-methionine and $\mathrm{N}$-acetylcysteine protective effects on acetaminophen hepatic toxicity. JPET. 2007; 320:1-9.

24. Wu YL, Piao DM, Han XH, Nan JX. Protective effects of salidroside againts acetaminopheninduced toxicity in mice. Biol Pharm Bull. 2008; 31:1523-9.

25. Kim YR, Lee NJ, Ban JO, Yoo HS, Lee YM, Yoon $\mathrm{YP}$, et al. Curative effects of thiacremonone againts acetaminophen-induced acute hepatic failure via inhibition of proinflammatory cytokines production and infiltration of cytotoxic immune cells and kupffer cells. Evidence Based Complementary and Alternative Medicine. 2013; 4:1-13.

26. Carvalho NR, Rosa EF, Silva MH, Tassi CC, Dalla $\mathrm{CL}$, et al. New therapeutic approach: diphenyl diselenide reduces mitochondrial dysfunction in acetaminophen-induced acute liver failure. PlosOne. 2013;8:1-13. 